\title{
The road they share: the social conflict element in Marx, Keynes and Kalecki
}

\author{
Pablo Gabriel Bortz* \\ National University of San Martín, Argentina
}

This paper sets out to find commonalities and divergences in the writings of Marx, Kalecki and Keynes regarding their analysis of social (class) conflict in capitalist societies. We find evidence that shows that, contrary to a harmonious view of society, Keynes had a class stratification of society and an understanding of conflictive interests and developments compatible with that of Marx and Kalecki. The presence of political motivations as fuel for economic instability is another shared element between Kalecki and Keynes. Differences arise regarding the relative importance of the inter-and intra-class dynamic as a driver of distributive conflict, and the State's capabilities to guide or control those conflicts and their consequences.

Keywords: Keynes, Kalecki, Marx, social conflict, fiscal policy, interest rate

JEL codes: $B 14, B 31, D 74, E 22, E 64$

\section{INTRODUCTION}

'The class war will find me on the side of the educated bourgeoisie', Keynes famously stated in his pamphlet 'Am I a liberal?' (CW IX, p. 297). ${ }^{1}$ His political affiliations have been the object of several analyses (Skidelsky 2003; Dostaler 2007, among others). It is widely known that he rejected Marxism, and particularly Marx's theory, even though on many occasions he made use of some of Marx's concepts, such as the monetary circulation scheme. It is understood that Keynes sought to protect capitalism by changing it from within. This paper seeks to explore a different aspect of Keynes's theory, not focusing on his political actions and tastes, but on the political corollaries of his theory. We aim to understand the role of conflict and social struggle; whether it implies a harmonious view of (capitalist) society such as in the marginalist theory (as presented by Jevons or John Bates Clark, for instance); or whether it reflects a struggle, divergence and incompatibilities in the interest of the different classes of society that expresses itself in an economic behaviour full of macroeconomic consequences. We are also interested in Keynes's acknowledgement of the political obstacles faced by the policy choices implied by these theoretical corollaries, both in domestic and international affairs.

* Email: pablobortz@yahoo.com. The author thanks Ariel Dvoskin, Louis-Philippe Rochon, Matías Vernengo and two anonymous referees for their comments. All errors are the author's responsibility.

1. CW stands for The Collected Writings of John Maynard Keynes (Keynes 1973-1989). 
It seems natural to compare this role with the theories of the other two major economists who adopted a class stratification structure when developing their analyses of capitalism, namely Karl Marx and Michał Kalecki. Marx is known to define class struggle, or social conflict, as the engine of history. In a capitalist society, the search for higher profits through cost-cutting innovation and labour-saving investment eventually produces the opposite effect by leading to falling profit rates and accumulation crises. Giving in to this analysis, Bismarck developed what we call today a welfare state, in order to support a minimal standard of living for the working poor and the disabled, effectively sustaining a certain demand level. It would not be stretching the imagination too far to say that such appeasing policies, which seem to have got the approval of Kalecki and Keynes, would reflect a social cooperation view identifiable with the writings of these authors. ${ }^{2}$ However, it is the contention of this paper that Kalecki's and Keynes's view and theories on the topic have more in common with Marx than a casual reading might suggest. That is not surprising for the case of Kalecki, who was himself inspired by authors such as Rosa Luxemburg and Mikhail Tugan-Baranovsky, but also in the case of Keynes, a careful reading will show that a class structure also permeates his view and analysis, with conflicting interest among and within them.

The paper is structured as follows, with the clarification that we will restrict our focus to writings referring to capitalism. Section 2 reviews the role of intra- and inter-class conflict in Marx's analysis, using it as the background or benchmark for comparison throughout the paper. Section 3 reviews Kalecki's writings on the topic under discussion, while Section 4 surveys Keynes's writings, quoting extensively in order to reflect a consistent view of the political factors, inextricably linked with class interests, involved in the description, diagnosis and policy prescriptions for the maladies of capitalist economies. Section 5 concludes.

\section{SOCIAL CONFLICT IN MARX}

Not much space will be spent (or invested) in explaining the role of conflict in Marx's theory. At this stage, only a few axes of analysis will be defined in order to set the tone and the guidelines for the comparison with Kalecki's and Keynes's view, since a large literature already exists on Marx and there is hardly any contribution we could add to it. Furthermore, we will restrict our considerations mostly to what Marx expressed in Das Kapital.

The social structure of production determines the class structure of the society, meaning the ownership regime of the means of production, and the relationship between the owners of such means of production and the workers. In a capitalist society, those means of production adopt the name of 'capital', being a social relationship which separates its owners from the free men that act as workers. Different societies have different structures (slavery societies, feudalism, etc.), and all breed conflict between them as regards the motivation for changes in the structure of production and the appropriation of the (smaller or greater) surplus produced over the reproduction needs of workers (be they slaves, servants or wage-earners). The way conflict is channelled may well result in a change of the regime itself, as has historically happened at different times in different societies.

2. See Skidelsky (2003, pp. 708-724) and Marcuzzo (2010) for studies on the relation between Keynes and Beveridge (and his welfare plan). 
As regards capitalism, conflict displays itself in a number of ways, of which we will mention a few. First, between owners of means of production and free owners of their labour power, the use of which provides their sole means to earn their living. By virtue of their owners' status, capitalists can retain a portion of what workers produce with their means of production, a portion capitalists always struggle to increase at the relative expense of workers. The means by which they try to do this, however, ends up endangering the very survival of capitalism, a kind of macroeconomic paradox, the first of many that will be mentioned throughout this paper.

The story about the struggle over the appropriation of income has two sides, in Marx's theory: a long-run (or long-period) aspect, and a cyclical one (Levrero 2013). The real wage tends to stabilize around a long-term level corresponding to the subsistence requirements of the labour force, 'subsistence requirements' being loosely understood as to accommodate patterns of consumption according to the specific, historically determined social environment of the labour force. This is the minimum real-wage level that allows the reproduction of the labour force in accordance with the characteristics of the prevalent production system. Then comes the question of how capitalism manages to maintain the real wage at this long-term level, particularly being such a progressive system in terms of the impulse to develop productive capacities.

The question is more intriguing given that, in Marx's theory, as accumulation accelerates during the boom phase, it demands more and more workers, pushing up the real (and nominal) wage level. Though the labour supply is fairly elastic, the bargaining power of workers increases and they enjoy more than their minimum reproductive needs, at the expense of capitalists' profits (both in terms of shares and rates). ${ }^{3}$

If profits are threatened to the point where 'the stimulus of gain is blunted' (Marx 1867, ch. XXV, sec. 1), however, accumulation slows down and unemployment increases. 'The rate of accumulation lessens; but with its lessening, the primary cause of that lessening vanishes, i.e., the disproportion between capital and exploitable labour power. ... The price of labour falls again to a level corresponding with the needs of the self-expansion of capital' (ibid.).

On top of this cyclical mechanism for checking the rise of wages, capitalists have another weapon to refill the pool of the available workforce and prevent wages from rising above their 'natural' level. In the face of rising wages, labour-saving, capitalintensive technologies are adopted. The labour-to-capital ratio is reduced, and accumulation can proceed without being obliterated or restricted by the scarcity of workers. The 'industrial reserve army of labour' is replenished and workers see their bargaining power diminished. The effect of this automation goes well beyond the employment level (or rates of growth). Unlike the previous traditional manufacture, in the new factories workers lose their power over the productive process, are de-skilled and no longer able to set the rhythm of work, among other implications. Luddites had the rational incentive to destroy those machines.

The unstoppable impulse to invest arising out of competition, the unending quest for lowering the wage share, leads to the replacing of circulating capital (mainly wages) by fixed capital, increasing labour productivity. However, for Marx this factor does not fully compensate for the detrimental effect of a higher capital stock on profitability, so that a rising profit share goes hand-in-hand with a falling profit rate. This is

3. This implies that firms operate, in Marx's settings, at a constant rate of capacity utilization (Sardoni 2015). 
the so-called 'falling trend of the rate of profit' ${ }^{4}$ By seeking to increase their profits at the (relative) expense of labour, capitalists end up obstructing the very engine of capitalist development, and setting the stage for an ulterior social mode of production.

The secular decline in the income share of labour has another detrimental consequence for the stability of capitalism. As stated by Marx:

The conditions of direct exploitation, and those of realising it, are not identical. They diverge not only in place and time, but also logically. The first are only limited by the productive power of society, the latter by the proportional relation of the various branches of production and the consumer power of society. But this last-named is not determined either by the absolute productive power, or by the absolute consumer power, but by the consumer power based on antagonistic conditions of distribution, which reduce the consumption of the bulk of society to a minimum varying within more or less narrow limits. It is furthermore restricted by the tendency to accumulate, the drive to expand capital and produce surplus-value on an extended scale. (Marx 1894, ch. XV, sec. 1)

In our view, this effect is of a different nature than the implications of the "falling trend of the rate of profit'. ${ }^{5}$ The latter refers to a long-term fall in the inducement to invest, without any regard for the evolution of aggregate demand; while the former, the so-called 'realization problem', deals precisely with the actual disappointment of such expectations, in a manner quite compatible with Kalecki's or Keynes's theories. Both problems are due to the consequences and development of a distributive struggle; however, the 'realization problem' is more amenable to conscious demand management as a possible way to overcome it.

Summing up, for the purposes of our discussion we have highlighted three types of class conflict in Marx, inherent to a capitalist system: the main one, that defines the system and is the very engine of its change and transformation, between capital and labour, in which capitalists use cyclical crises as a means to force a restructure of capital and a redundancy in the labour force, preventing wages from rising; another version of that same conflict, fostered by the attempt to economize on the work force by adopting labour-saving, technology-intensive capital equipment; and the conflict between capitalists for appropriation of surplus value, compelling them to invest. This compulsion to invest in technology-intensive techniques and to expand production, coupled with the relative reduction of the wage share of income, has the double effect of reducing the consumption capabilities of the economies (though Marx does not mention any awareness of capitalists about this implication) and a tendency for the rate of profit to fall, since the gains in labour productivity (and the rise of the profit share) are counteracted by an increase in the capital-to-output ratio. We can also mention interest payments (and other types of rents) as distributing profits from capitalists to creditors as another potential intra-capital conflict for the appropriation of the surplus value of the whole economy. Against this background, we will see next how Kalecki's and Keynes's theories reflected (or not) these intrinsic conflicts present in Marx, and whether they developed their own.

4. He did qualify this argument by noticing counteracting forces to this tendency, among which he included higher productivity growth (that lowered the unitary value of fixed capital); a higher degree of exploitation; foreign trade as it may lower the value of necessity goods (as in Ricardo's example); and the industrial reserve army, as it provides workers for newly established industries at below-average wages (Marx 1894, ch. XIV).

5. Alternative interpretations are to be found both in Sweezy (1942) and in Pivetti (2015), among others. 


\section{SOCIAL CONFLICT IN KALECKI}

If one would try to capture the role of social conflict in Kalecki's theory, the following summary would lead us fairly well to the core of his argument: a laissez-faire capitalist system was unlikely to provide sustained full employment. Instead, and even moreso after the theoretical and political developments in the 1930s, public interventions could be devised to assure the maintenance of full employment. However, this state of affairs, if prolonged, would produce a marked social change and face political backlash from the business classes, requiring stronger involvement and struggle of the working class. Conflict influences policy choices from different sectors to achieve their interest. ${ }^{6}$

But before presenting his vision with greater care, it is necessary to give a bit of intellectual context regarding Kalecki's development as a theorist. Having been a socialist sympathizer throughout his life (Osiatynski 1990, p. 428), Kalecki was self-educated in economics, and his Marxian background (with his readings of Tugan-Baranowski, Lenin, Rosa Luxemburg and others) led him to develop a social stratification vision, in which agents are classified according to social (income) groups distinguishing between wage-earners and capitalists, including from time to time rentiers as well. The influence of the Swedish/Norwegian writers of his time (Frisch, Myrdal, Ohlin, all of whom he met/worked with) also imbued him with the distinction between ex ante and ex post, and generally with the possibility of macroeconomic paradoxes in which agents' plans might not be realized at the aggregate level. Though his early writings had a distinct Say's law flavour, in which savings determine investments, ${ }^{7}$ around 1933 Kalecki turned to the vision that would mark his professional life and put him on a footing with Keynes as the pioneers of the principle of effective demand, in which expenditure determines income, and investment determines savings.

These three basic pillars (that is, the Marxist background with class stratification; the possibility of macroeconomic outcomes contrary to the objective of individual agents when acting in a certain way; and the principle of effective demand) provide the context to analyse with further detail what was presented at the beginning of the section.

In Kalecki's writings, business cycles are an unavoidable feature of a laissez-faire economy, and are driven by investment decisions that take some time to materialize. Though he used different lags at different stages with different purposes (with at times a more empirical or more theoretical emphasis), one can sum up by saying that he distinguished between the time an investment decision was made and the time the investment good was delivered. Investment decisions were determined by profit expectations, into which present and recent experience weighs heavily. And current profits are determined (in a closed economy with no government activity and no workers' savings) by current expenditure, notably current investment and (non-wage-earners) consumption:

Investment or consumption of some capitalists creates profits for others. Capitalists as a class gain exactly as much as they invest or consume, and if - in a closed system - they ceased to construct and consume they could not make any money at all. Thus capitalists, as a whole, determine their own profits by the extent of their investment and personal consumption. (Osiatynski 1990, p. 79)

6. About Kalecki's life and theory, see Feiwel (1975), Sawyer (1985), López and Assous (2012) and Toporowski (2013).

7. See, for instance, Osiatynski (1990, pp. 15-25). 
Acts of investment called for further expansion of consumption goods (because they increased the employment in the investment sector), which fed back to investment orders. But as investment goods entered into the productive capacity and surpassed depreciation needs, the capital stock started to rise, capacity utilization started to decrease, and profits started to fall. Investment decisions started to pale, but capital goods kept coming out of the oven, since they were determined by previous decisions. The boom was doomed, and recessions kicked in. At the bottom of the cycle the capital stock was replaced at a slower rate than depreciation needs and the cycle moved on to the next phase. Though Kalecki's faith in the speed and occurrence of recovery changed from time to time, ${ }^{8}$ he was emphatic that in a laissez-faire system investment fluctuates violently (Osiatynski 1990, p. 365).

Fiscal austerity was not effective in lifting the economy out of a slump, particularly in a context in which the unemployed are heavily indebted (ibid., p. 176), an argument closely resembling the 'balance-sheet recession' hypothesis by Koo (2014). The other traditional way spouted by mainstream economists at the time was to cut wages, and they were equally counterproductive, since inventories would accumulate due to lower consumption by workers, and/or prices would fall, according to the different degree of cartelization of the economy. Though some individual entrepreneur might be satisfied with the fall observed in their costs, they would see their sales fall, and wage cuts would be self-abortive.

Class struggle, in this way, was one of the main determinants of income distribution, together with the movement of non-labour inputs (notably, raw materials). The price of raw materials tended to rise in the upswing and fall in the downswing, but the degree of monopoly tended to be counter-cyclical, to some extent in agreement with Marx. These movements tended to compensate each other at the time Kalecki wrote, leading to a fairly stable wage share in national income in developed economies, one of Kaldor's 'stylized facts'. However, if trade unions followed the advice of certain 'workers' friends' and did not resist wage falls as a way to increase employment, their share of income would certainly drop (Osiatynski 1990, p. 284). In one of his last articles reprinted in Kalecki (1971), he pointed out that greater wage-bargaining power could not only modify the degree of monopoly, but even positively impact the level of employment (a qualification that was absent in early writings), through its effect on the output of the consumption goods sector, and redistribute profits between capitalists. This effect, and the ineffectiveness of wage cuts as a means to overcome crises, is one of the main differences between Kalecki and Marx.

But just as wage bargaining can foster employment, so can a conscious economic policy. In 1943 Kalecki starts a paper (that has been making the rounds in 2017) by stating that

a solid majority of economists is now of the opinion that, even in a capitalist system, full employment may be secured by a government spending programme, provided there is in existence an adequate plan to employ all existing labour power, and provided adequate supplies of necessary foreign raw-materials may be obtained in exchange for exports (Kalecki 1971, p. 78)

by means of public investment or subsidizing mass consumption by means of borrowing (Osiatynski 1990, p. 347). That is, there was the theoretical understanding to attenuate (or eliminate) the business cycle, with the mechanisms to sustain a prolonged period of full employment. The paper is called 'Political aspects of full employment'. The policy

8. Compare Osiatinski (1990, p. 77) with Kalecki (1971, p. 133). 
alternatives are further discussed in a 1944 article (included in Osiatynski 1990, pp. 357-376), in which Kalecki rejects the direct stimulus to private investment (by lowering the interest rate, or income taxes), in favour of progressive income distribution or government subsidies to mass consumption.

However, two things are worth mentioning at this stage. First, Kalecki was not in favour of the use of public investment as a way to secure full employment; rather, he limited investment to the role of building up the productive capacity to sustain such a level. There was one exception, though, and that referred to the case of labour-saving (and capital-intensive) technological progress, in which Marx's falling trend of the rate of profit kicked in: the capital to potential (or full-employment) output ratio may be constant, but the capacity-utilization ratio (actual to potential output) may be falling, and therefore lowering private investment. In that case, public investment had two uses, as a creator of productive capacity and as a source of effective demand.

The second point is that, even though there is the theoretical understanding of the policies required to sustain full employment, the political obstacles are considerable. In fact, the mistrust in the stimulus of private investment as the preferred policy to maintain full employment stems from two arguments: (i) the fall in interest rates or incometax rates would have to be cumulative in order to sustain full employment, diminishing its impact at each successive implementation (Osiatynski 1990, p. 377); ${ }^{9}$ and (ii) its positive impact would depend on the mood and confidence of entrepreneurs, which gives them a powerful tool to influence the political and economic orientation of the government. It is no coincidence that this is the preferred government intervention by business interests (ibid., p. 353).

The objections to government intervention go further than that. In fact, Kalecki states that business interests oppose the very maintenance of full employment levels, since unemployment loses its disciplinary power, and trade unions become more energetic. "Discipline in the factories" and "political stability" are more appreciated than profits by business leaders' (ibid., p. 351). As we mentioned before, trade unions can force a fall in the degree of monopoly at the aggregate level and redistribute income in their favour, with wages rising more than prices. However, this policy would not only hurt the capitalist class. It would also damage the real income of rentiers, who would not hesitate to exert pressure for a change in the economic orientation, leading to a slump and a rise of unemployment (ibid., p. 355). It is with this thought in mind that we begin to tackle Keynes's analysis, with a focus on his more mature writings.

\section{SOCIAL CONFLICT IN KEYNES}

In order to explain events and past, present and future developments, Keynes allowed for a much greater influence of ideas (as opposed to vested interests) than Marx or Kalecki did, as shown in academic (CW VII, p. 384) and in more popular publications (CW XXI, pp. 61 and 294). Kingsley Martin, then editor of The New Statesman, chastised Keynes for 'attributing too much to the deficiencies of personnel and too little to the "contradictions" of our system', in an interview in which Keynes stressed instead the 'out-of-datedness of mind' of government authorities (CW XXI, pp. 498-499).

9. Kalecki's discussion of the continuous fall in the interest rate is very similar to the argument that stresses the counterproductive impact of negative interest rates on reserves as a way to stimulate the supply of credit (Osiatynski 1990, pp. 405-406). His description of what is nowadays called 'quantitative easing' is also spot on (ibid., p. 403). 
And he was all for avoiding class war (CW XIX, p. 324), though he was quite certain where would he stand, should he have to take a side, as mentioned at the beginning of this paper.

However, he was not oblivious either, to the political consequences, obstacles and requirements of behaviour, interests and solutions related to the economic difficulties in a capitalist economy. The thesis of this paper is that his theory and corollaries reflect just that, and that is what we will try to convey in this section. Unless necessary, however, we will refrain from commenting on Keynes's political orientations. A large literature exists on them, and we mentioned a few examples in Section 1.

One of the social illnesses present throughout most of Keynes's academic life, particularly after the First World War, was mass unemployment, and two of the remedies advanced by the mainstream of the profession were real wage cuts (by means of lowering nominal wages) and general austerity, be it by the private sector or by the government. Keynes, instead, saw that what may initially seem beneficial to a single entrepreneur, individually considered, may have repercussions for the class as a whole, and with multiplied effect if both remedies are attempted at the same time.

Nevertheless these courses will in actual fact appeal to [the entrepreneurs], because, in so far as any class of entrepreneurs is able to adopt either of these courses in a degree greater than the average, they will be able to protect themselves. ... By however much entrepreneurs reduce wages and however many of their employees they throw out of work, they will continue to make losses so long as the community continues to save in excess of new investment. (CW V, pp. 144-145 and 160)

An increase in the individual propensity to save is futile for the community as a whole. Public intervention is a more elevated response to a natural state of inter-class conflict which feeds into itself, as was elaborated by the underconsumptionist theorists for whom Keynes felt sympathy.

The wage setting process, in fact, was not about the real wage (which trade unions were unable to set), but about the nominal wage. Ultimately, wage bargaining seen from the point of view of trade unions was a negotiation about relative wages among workers. 'The struggle about money-wages primarily affects the distribution of the aggregate real wage between different labour-groups, and not its average amount per unit of employment' (CW VII, p. 14, emphasis in the original). More so: continued reductions in nominal wages actually increase price instability and reduce investment and employment because calculations about future incomes will be impaired and costs on current equipment will be increased (ibid., pp. 265-269). A general stability of wages, therefore, is not only a practical feature of modern economies with collective institutions setting nominal wages, but also a beneficial feature in a capitalist economy, unlike under a communist or fascist regime. Furthermore, Keynes was concerned that Kalecki's point in the aforementioned paper 'Political aspects of full employment' was correct, as mentioned in a letter to Benjamin Graham dated 31 December 1943:

Some people over here are accustomed to argue that the fear of unemployment and the recurrent experience of it are the only means by which, in past practice, trade unions have been prevented from over-doing their wage-raising pressure. I hope it is not true. ... The task of keeping efficiency wages reasonably stable (I am sure they will creep up steadily in spite of our best efforts) is a political rather than an economic problem. In my country it is quite essential that it should not be handled in obedience to the dictates of an international currency system. (CW XXVI, pp. 37-38) 
Not publicly known, Keynes had sent a letter to Kalecki 11 days earlier stating his sympathy, interest and agreement with that paper. 'An exceedingly good article and very acute. If I have been writing it myself, I might have added as an important influence ... old fashioned sound finance which [resists (?) illegible] against any public expenditures and a high deficit...' (quoted in Osiatynski 1990, p. 573). Economic prosperity is 'excessively dependent on a political and social atmosphere which is congenial to the average business man' (CW VII, p. 162). We will return later to the issue of the 'priests' of sound finance, but these texts speak volumes about Keynes's view of political oppositions to the maintenance of a full employment policy, and the use of investment and unemployment as a weapon by business leaders and financiers to advance their interests, by refraining from productive investment, and preferring instead liquid and 'safe' assets, including capital flight. The inducement to invest (the marginal efficiency of capital) is very sensitive to such changes of mood in the minds of investors, in a laissez-faire economy.

The other variable that influences investment is the interest rate. The short-term interest rate is determined by the central bank but the long-term rate, itself built on expectations of future short-term rates, is more open to market influences (CW VII, p. 203). In Keynes's work it is determined by the liquidity preference of the public, what they demand to part with liquidity. His definition of the nature of the long-rate of interest is worth quoting in full:

[T] he rate of interest is a highly conventional, rather than psychological, phenomenon. For its actual value is largely governed by the prevailing view as to what its value is expected to be. Any level of interest which is accepted with sufficient conviction as likely to be durable will be durable (ibidem). An unstable marginal efficiency of capital is faced with a conventional and stable long-term rate of interest, unlikely to fall by normal market forces to levels compatible with high employment rates. (CW XXI, p. 240, emphases in the original)

Why is that so? We interpret Keynes's theory as presenting four main reasons, in a private organized economy. First, the fetish of liquidity, the organizing doctrine for investment. This increases the elasticity of financially speculative decisions with respect to the interest rate.

With this liquidity in mind, and remembering that the long-term rate is built on the expectations of future short-term rates, the second reason is that very limited changes in these expectations can lead to substantial losses on long-term investment: 'a longterm rate of interest of (say) 2 per cent leaves more to fear than to hope, and offers, at the same time, a running yield which is only sufficient to offset a very small measure of fear' (CW VII, p. 202). It is not a coincidence that that is the percentage that 'John Bull' cannot stand for too long, as Bagehot (1873, pp. 138-139) said.

It is not a coincidence either that in earlier societies land was the asset with a liquidity premium charged by wealth owners, a premium that discouraged lending for productive purposes. And it is this premium that Keynes wanted to lower, bringing down the return on usury relative to the return on enterprise and risk (CW XXI, p. 412). The fall in the return of usury is nothing but an attack on the income of the rentier, a requirement for long-term growth in a laissez-faire economy (Lavoie and Seccareccia 1988). This is the third reason we highlight: the opposition of the wealth-owner class to a fall in its income determinant, the call of the priests of sound finance.

The fourth reason refers to the international sphere. In an international financial system with free movement of capital, the lower limit to the interest rate is set by the international rate of reference, and the central bank is obliged to preserve the external equilibrium. The implications of this are huge, for it gives domestic investors a veto 
power on the economic orientation of the government. 'If English investors, not liking the outlook at home, fearing labour disputes or nervous about a change of government, begin to buy more American securities than before ... it will, in the first instance, set up a serious instability of the domestic credit system' (CW VI, p. 300; see also CW XXI, p. 366). Changes in the mood of financial investors, both foreign and domestic may force the central bank to adopt measures with depressive influences at home. At the time of the Bretton Woods negotiations, another factor was also relevant: the expansion of communism to Eastern Europe menaced the position of the wealthy, who might flee their home country. Capital movements were likely to be caused by political issues.

The most ardent defence of capital controls developed by Keynes came in a response to a 1942 memorandum on the strategy for Britain in the negotiations with the United States about future postwar arrangements. The writer of this memo was none other than Roy Harrod, who lists in the appendix his reasons for opposing capital controls (Harrod 1942). Harrod (ibid., pp. 24-26) questions the move to autarky, against 'enterprising spirit and initiative', resembling the 'Schachtian way of thinking', limiting the foreign exchange that British speculators might be able to gain abroad.

Keynes had a distaste for capital movements from early on, as explained by Flanders (1989). In his reply to Harrod's memorandum, also quoted by Crotty (1983), Keynes listed the political factors mentioned above as an argument in favour of capital controls. But fundamentally, 'in my view the whole management of the domestic economy depends upon being free to have the appropriate rate of interest without reference to the rates prevailing elsewhere in the world. Capital control is a corollary to this' (CW XXV, p. 149).

Capital controls (which might involve the whole control of foreign exchange, in his view) would be the policy response to our listed reason number four. Keynes also sought the involvement of public authorities to solve the other three, with different instruments. The three axes of actions are: to increase the average propensity to consume of the community by means of redistribution (preferably through an income tax policy); to lower the long-term rate of interest; and to carry public investment plans together with a comprehensive management of the rate of investment, also in private hands.

Income distribution in favour of the class more likely to spend it is a requirement for fostering capital investment (CW VII, pp. 372-373; see also Bortz 2016, ch. 2). A faltering effective demand is not conducive to obtaining a proper reward for productive investment (CW VII, pp. 380-381). Keynes was very enthusiastic about Kalecki's plans for an income-tax policy presented in 'Three ways to full employment' (1944, included in Osiatynski 1990, pp. 357-376), as reflected in his letter to Kalecki himself (CW XXVII, pp. 381-383, also reproduced in Osiatynski 1990, pp. 579-580).

Though the long-term rate of interest is more sensitive to market mood than the short-term rate, Keynes stressed that the central bank has the knowledge and the power to bring it to the level of its choice (exception made for its divergence with the international rate of reference). In the Treatise on Money Keynes had recommended that the central bank intervenes in the whole structure of interest rate. ${ }^{10}$ In a paper recently rediscovered by Tily (2015), Keynes not only granted the central bank the power to control it, but also discouraged its use to fine-tune the economy, that

10. See Kregel $(2011 ; 2014)$ for a review and criticism of Keynes's suggested instruments to control the interest rate both in the Treatise on Money and in The General Theory, some of which resemble the modern implementation of quantitative easing. 
is, to increase the long-term interest rate so as to cool down the economy. Its use for that purpose would render it ineffective in the slump as well. On the contrary, it should be parked at what is assumed to be its long-term optimum. ${ }^{11}$

It is the use of public expenditure and the regulation of the rate of aggregate investment that are Keynes's preferred methods to control the pace of economic activity. Already in 1924 Keynes advocated the State to step forward and stimulate or execute investment projects that the private sector was unwilling to conduct (CW XIX, pp. 219-232). In the framework of The General Theory, fluctuations in the marginal efficiency of capital might be so large as to be counteracted by reasonable movements in the interest rate, so that a public guidance of investment is required, under his slogan of the socialization of investment. He accepted alternative methods such as a stimulus of consumption (the preference of Kalecki, as we saw) to fine-tune the economy during short-term fluctuations, but he favoured changing the rate of investment $(\mathrm{CW}$ XXVII, p. 361). In short, the arrangement of policy choices at the disposal of the government was not a secret and continued to be developed, including several contributions by Keynes himself. He attributed many of the contradictions observed in his writings to the fact, in his own words, that in some cases he had 'more particular circumstances in mind and [was] more inclined to agree to compromises which may prove practically acceptable' (CW XI, p. 501). ${ }^{12}$ His 'realistic' approach to economic policy-making is also implied by Colander (1984), regarding Keynes's approval of Lernerian policies, though doubting the political possibilities of such enterprise. The capabilities of the State to sustain high levels of full employment were not doubted. Neither were the political obstacles that it must attack, both at home and in the international (monetary) sphere.

\section{CONCLUSION}

The similarities and points in common between the theories of the three writers were recognized shortly after the publication of Keynes's General Theory and as Kalecki became a more familiar name. ${ }^{13}$ About the topic of this paper, just like Marx and just like Kalecki, Keynes interpreted the laissez-faire capitalist economy as crossed by deep social conflict that had a substantial bearing on the economic performance. Just like the two previously mentioned authors, Keynes saw in the differential appeal of different behaviours for the individual and the community as a whole (and within social classes as well) one of the roots of economic volatility and ultimate failure to provide sustained full employment and a decent living standard.

And he also saw, just like them too, divergent class interests as a cause for economic retardation. Unlike Marx, who stressed the class struggle between capital and labour (as, to some extent, did Kalecki), Keynes put the emphasis on the obstacles

11. In terms of Rochon and Setterfield (2007), Keynes would belong to the 'parking it' approach. See also Lavoie (1999).

12. This phrase is contained in a letter, written on 13 October 1936, to Willy Lück, then a graduate student at Leipzig. This letter is very important, since it reveals Keynes's preferred exchange-rate arrangements prior to Bretton Woods. Though it escapes the scope of this paper, based on it one could argue that Keynes favoured a bands exchange-rate system, with a 10 per cent fluctuation range.

13. A short summary is provided in Pivetti (2015, p. 137), to which we can certainly add Sweezy (1942). 
set by the wealthy, rentier class by means of its imposition of liquidity premiums on investment. In that way, that class prevented the management of the interest rate (and credit conditions) in a way more conducive to social welfare. Keynes came close in this regard to Ricardo.

Both Keynes and Kalecki believed in the theoretical and practical capabilities of the State to consciously devise the appropriate measures to assure full employment, and advanced several proposals in this regard, both on the domestic and on the international scale. At the same time, both were equally aware of the political obstacles such an enterprise would face in reality, as the writings and letter exchange presented here reflect. In more public interventions, however, Keynes had an optimism of the spirit, which was not present to the same degree in Kalecki.

\section{REFERENCES}

Bagehot, W. (1873), Lombard Street: A Description of the Money Market, London: Henry S. King.

Bortz, P.G. (2016), Inequality, Growth and 'Hot Money', Cheltenham, UK and Northampton, MA: Edward Elgar.

Colander, D. (1984), 'Was Keynes a Keynesian or a Lernerian?', Journal of Economic Literature, 22(4), 1572-1575.

Crotty, J. (1983), 'On Keynes and capital flight', Journal of Economic Literature, 21(1), 59-65.

Dostaler, G. (2007), Keynes and his Battles, Cheltenham, UK and Northampton, MA: Edward Elgar.

Feiwel, G.R. (1975), The Intellectual Capital of Michal Kalecki, Knoxville, TN: University of Tennessee Press.

Flanders, M.J. (1989), International Monetary Economics 1870-1960, Cambridge, UK: Cambridge University Press.

Harrod, R.F. (1942), 'Forthcoming conversation with the United States on economic questions', memorandum, available at: http://www.lib.e.u-tokyo.ac.jp/_old/keynes_harrod/pdf/81/pdf.

Kalecki, M. (1971), Selected Essays on the Dynamics of the Capitalist Economy 1933-1970, Cambridge, UK: Cambridge University Press.

Keynes, J.M. (1973-1989), The Collected Writings of John Maynard Keynes, Cambridge, UK: Cambridge University Press for the Royal Economic Society, volumes as follows:

Volume V: Treatise on Money. The Pure Theory of Money.

Volume VI: Treatise on Money. The Applied Theory of Money.

Volume VII: The General Theory of Employment, Interest and Money.

Volume IX: Essays in Persuasion.

Volume XI: Economic Articles and Correspondence: Academic.

Volume XIX: Activities 1922-1929: The Return to Gold and Industrial Policy.

Volume XXI: Activities 1931-1939: World Crises and Policies in Britain and America.

Volume XXV: Activities 1940-1944: Shaping the Post-War World, The Clearing Union.

Volume XXVI: Activities 1941-1946: Shaping the Post-War World, Bretton Woods and Reparations.

Volume XXVII: Activities 1940-1946: Shaping the Post-War World, Employment and Commodities.

Koo, R. (2014), The Escape from Balance Sheet Recession and the QE Trap: A Hazardous Road for the World Economy, Hoboken, NJ: Wiley.

Kregel, J.A. (2011), 'Was Keynes's monetary policy, à Outrance in the Treatise, a frontrunner of ZIRP and QE? Did he change his mind in the General Theory?', Policy Note 2011/4, Levy Economics Institute of Bard College.

Kregel, J.A. (2014), 'Liquidity preference and the entry and exit to ZIRP and QE', Policy Note 2014/5, Levy Economics Institute of Bard College. 
Lavoie, M. (1999), 'Fair rates of interest and Post-Keynesian economics: the Canadian case', paper presented at the University of Bourgogne.

Lavoie, M. and M. Seccareccia (1988), 'Money, interest and rentiers: the twilight of rentier capitalism in Keynes's General Theory', in O.F. Hamouda and J. Smithin (eds): Keynes and Public Policy after Fifty Years, Volume II, Aldershot, UK and Brookfield, VT: Edward Elgar, pp. 145-158.

Levrero, E. (2013), 'Marx on absolute and relative wages and the modern theory of distribution', Review of Political Economy, 25(1), 91-116.

López, J.G. and M. Assous (2012), Michal Kalecki, Basingstoke, UK: Palgrave Macmillan.

Marcuzzo, M.C. (2010), 'Whose welfare state: Beveridge versus Keynes', in R. Backhouse and T. Nishizawa (eds): No Wealth but Life: Welfare Economics and the Welfare State in Britain 1880-1945, Cambridge, UK: Cambridge University Press, pp. 189-206.

Marx, K. (1867): Das Kapital, Volume I, available at: https://www.marxists.org/archive/marx/ works/1867-c1/index.htm.

Marx, K. (1894): Das Kapital, Volume III, available at: https://www.marxists.org/archive/marx/ works/1867-c1/index.htm.

Osiatynski, J. (1990), Collected Works of Michal Kalecki, Volume I: Capitalism: Business and Full Employment, Oxford: Oxford University Press.

Pivetti, M. (2015), 'Marx and the development of critical political economy', Review of Political Economy, 27(2), 134-153.

Rochon, L.-P. and M. Setterfield (2007), 'Interest rate, income distribution and monetary policy dominance: Post Keynesians and the "fair" rate of interest', Journal of Post Keynesian Economics, 30(1), 13-42.

Sardoni, C. (2015), 'Is a Marxist explanation of the current crisis possible?', Review of Keynesian Economics, 3(2), 143-157.

Sawyer, M. (1985), The Economics of Michal Kalecki, London: Macmillan.

Skidelsky, R. (2003), John Maynard Keynes 1883-1946: Economist, Philosopher, Statesman, London: Macmillan.

Sweezy, P. (1942), The Theory of Capitalist Development, New York: Oxford University Press.

Tily, G. (2015), 'The long-term rate of interest as Keynes's "villain of the piece", Real-World Economics Review, 73, 120-129.

Toporowski, J. (2013), Michal Kalecki: An Intellectual Biography, Basingstoke, UK: Palgrave Macmillan. 